\title{
INTERACTIONS OF IONIC LIQUIDS WITH URANIUM AND ITS BIOREDUCTION
}

\author{
Zhang, C. and Francis, A. J. \\ For presentation at the \\ International Conference 2011: Uranium, Mining and Hydrogeology VI, \\ Freiberg/Saxony, Germany \\ Sept. 18-22, 2011
}

July 2011

\section{Environmental Sciences Department/Energy Research and Technology Division \\ Brookhaven National Laboratory \\ P.O. Box 5000 \\ Upton, NY 11973-5000 \\ www.bnl.gov}




\section{DISCLAIMER}

This work was prepared as an account of work sponsored by an agency of the United States Government. Neither the United States Government nor any agency thereof, nor any of their employees, nor any of their contractors, subcontractors or their employees, makes any warranty, express or implied, or assumes any legal liability or responsibility for the accuracy, completeness, or any third party's use or the results of such use of any information, apparatus, product, or process disclosed, or represents that its use would not infringe privately owned rights. Reference herein to any specific commercial product, process, or service by trade name, trademark, manufacturer, or otherwise, does not necessarily constitute or imply its endorsement, recommendation, or favoring by the United States Government or any agency thereof or its contractors or subcontractors. The views and opinions of authors expressed herein do not necessarily state or reflect those of the United States Government or any agency thereof. 


\title{
Interactions of Ionic Liquids with Uranium and its Bioreduction
}

\author{
Chengdong Zhang ${ }^{1,3}$, Arokiasamy J Francis ${ }^{1,2}$ \\ ${ }^{1}$ Environmental Sciences Department, Brookhaven National Laboratory, Upton, \\ NY, USA; ${ }^{2}$ Division of Advanced Nuclear Engineering, Pohang University of \\ Science and Technology, Pohang, Korea \\ ${ }^{3}$ College of Environmental Science and Engineering, Nankai University, Tianjin, \\ China
}

\begin{abstract}
We investigated the influence of ionic liquids (ILs) 1-butyl-3methylimidazolium hexafluorophosphate $[\mathrm{BMIM}]^{+}\left[\mathrm{PF}_{6}\right]^{-}$, N-ethylpyridinium trifluoroacetate $[\mathrm{EtPy}]^{+}\left[\mathrm{CF}_{3} \mathrm{COO}\right]^{-}$and $\mathrm{N}$-ethylpyridinium tetrafluoroborate [Et$\mathrm{Py}]^{+}\left[\mathrm{BF}_{4}\right]^{-}$on uranium reduction by Clostridium sp. under anaerobic conditions. Potentiometric titration, UV-vis spectrophotometry, LC-MS and EXAFS analyses showed monodentate complexation between uranyl and $\mathrm{BF}_{4}^{-} \mathrm{PF}_{6}^{-}$; and bidentate complexation with $\mathrm{CF}_{3} \mathrm{COO}^{-}$. Ionic liquids affected the growth of Clostridium sp. as evidenced by decrease in optical density, changes in $\mathrm{pH}$, gas production, and the extent of U(VI) reduction and precipitation of U(IV) from solution. Reduction of $\mathrm{U}(\mathrm{VI})$ to $\mathrm{U}(\mathrm{IV})$ was observed in the presence of $[\mathrm{EtPy}]\left[\mathrm{BF}_{4}\right]$ and $[\mathrm{BMIM}]\left[\mathrm{PF}_{6}\right]$ but not with $[\mathrm{EtPy}]\left[\mathrm{CF}_{3} \mathrm{COO}\right]$.
\end{abstract}

\section{Introduction}

Ionic liquids (ILS) are ion-pair compounds containing an organic cation and an organic or inorganic anion. They are versatile since their chemical properties such as hydrophobicity, melting point and viscosity can be adjusted to obtain the desired reaction. They are used as green solvents in organic synthesis and in materials chemistry (Anastas and Warner, 1998). Visser et al. (2003) determined the molecular association of $\mathrm{UO}_{2}{ }^{2+}$ with hydrophobic ILs $\left[\mathrm{C}_{4} \mathrm{mim}\right]\left[\mathrm{PF}_{6}\right]$ and $\left[\mathrm{C}_{8} \mathrm{mim}\right]\left[\mathrm{N}\left(\mathrm{SO}_{2} \mathrm{CF}_{3}\right)_{2}\right]$ in the presence of CMPO and TBP using EXAFS. The uranium formed a $\mathrm{UO}_{2}\left(\mathrm{NO}_{3}{ }^{-}\right)(\mathrm{CMPO})$ complex in the IL phase while IL-associated anion complexation with uranium was not observed. Gaillard et al. (2005) used time-resolved emission spectroscopy and EXAFS analysis to determine the complexation ability of fluorinated anions with uranyl ion in aqueous solution at room temperature. Both $\left[\mathrm{BF}_{4}\right]^{-}$and $\left[\mathrm{PF}_{6}\right]^{-}$formed inner-sphere monodentate complexes with uranyl ion while $\left[\mathrm{Tf}_{2} \mathrm{~N}\right]^{-}$did not complex with uranium. 
2 1Environmental Sciences Department, Brookhaven National Laboratory, Upton, NY, USA; 2Division of Advanced Nuclear Engineering, Pohang University of Science and Technology, Pohang, Korea

Microbial reduction of uranium is of considerable interest because of its potential application in the bioremediation of contaminated sites and in the pretreatment of uranium containing wastes. In this study, we investigated the interaction of uranium (VI) with N-ethylpyridinium tetrafluoroborate [EtPy] $\left[\mathrm{BF}_{4}\right]$, 1-butyl-3-methylimidazolium hexafluorophosphate $[\mathrm{BMIM}]\left[\mathrm{PF}_{6}\right]$ and $\mathrm{N}$ ethylpyridinium trifluoroacetate [EtPy] $\left[\mathrm{CF}_{3} \mathrm{COO}\right]$, (Fig. 1) in aqueous solution and examined their effects on uranium reduction by anaerobic bacteria.

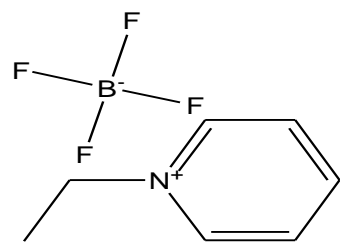

$\mathrm{EtPyBF}_{4}$

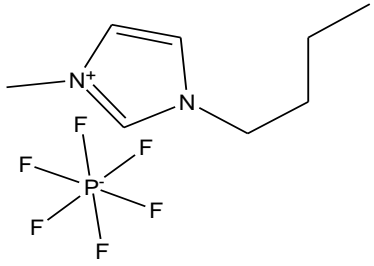

BMIMPF $_{6}$

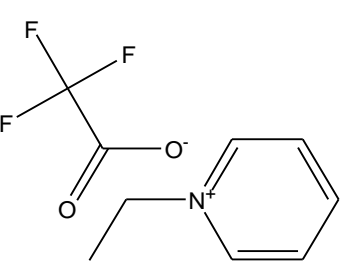

$\mathrm{EtPyCF}_{3} \mathrm{COO}$

Fig 1. Molecular structures of ILs N-ethylpyridinium tetrafluoroborate [Et$\mathrm{Py}]\left[\mathrm{BF}_{4}\right]$, 1-butyl-3-methylimidazolium hexafluorophosphate [BMIM] $\left[\mathrm{PF}_{6}\right]$ and N-ethylpyridinium trifluoroacetate $[\mathrm{EtPy}]\left[\mathrm{CF}_{3} \mathrm{COO}\right]$.

\section{Characterization of Uranium associated with ILs.}

Potentiometric titration. Potentiometric titration of uranyl nitrate showed the inflection point at $2 \mathrm{mM} \mathrm{OH}^{-} / \mathrm{mM} \mathrm{U}$ at pH 6.4 (Fig. 2). The release of 2 protons is due to the association of uranium ion with $2 \mathrm{OH}^{-}$in water. The titration curves for the U:[BMIM] $\left[\mathrm{PF}_{6}\right]$ and the $\mathrm{U}:[\mathrm{EtPy}]\left[\mathrm{BF}_{4}\right]$ with uranyl nitrate alone indicated no complex formation between the metal and the ILs. Addition of one-fold excess IL had no effect on the complexation. However, titration of the $\mathrm{U}$ in the presence of [EtPy] $\left[\mathrm{CF}_{3} \mathrm{COO}\right]$ showed a release of one more proton into the medium as indicated by the inflection point at $3 \mathrm{mM} \mathrm{OH}^{-} / \mathrm{mM}$ U. This phenomenon shows that there is an interaction of the uranium with the $[\mathrm{EtPy}]\left[\mathrm{CF}_{3} \mathrm{COO}\right]$. The interaction increases with addition of one-fold excess $[\mathrm{EtPy}]\left[\mathrm{CF}_{3} \mathrm{COO}\right]$ (more acid released).
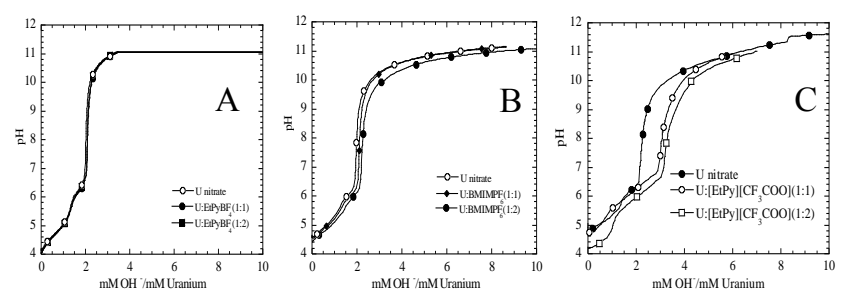

Fig 2. Potentiometric titration curve of $U$ and ILs mixture: (A) $[\mathrm{BMIM}]\left[\mathrm{PF}_{6}\right]$ (B) $[\mathrm{EtPy}]\left[\mathrm{BF}_{4}\right] ;(\mathrm{C})[\mathrm{EtPy}]\left[\mathrm{CF}_{3} \mathrm{COO}\right]$. 
UV-vis absorption spectroscopy. The UV-vis absorption spectrum for the $\mathrm{pH}$ unadjusted uranyl nitrate in the range of $300 \mathrm{~nm}$ to $500 \mathrm{~nm}$ showed fine structure in the $380 \mathrm{~nm}$ to $440 \mathrm{~nm}$ range characteristic of the presence of uranyl ion species. The maximum absorbance was at $413 \mathrm{~nm}$ and two shoulder peaks were noted at $402 \mathrm{~nm}$ and $425 \mathrm{~nm}$. The UV-vis absorbance spectra for the 1:1 U:[EtPy] $\left[\mathrm{BF}_{4}\right]$ and 1:2 U:[EtPy] $\left[\mathrm{BF}_{4}\right]$ mixtures showed the absorption maxima for both spectra are higher by 25 to $30 \%$ compared to uranyl nitrate alone and this enhanced absorption indicates there is interaction of the IL with uranium. However, the 1:1 and $1: 2$ of $\mathrm{U}:[\mathrm{BMIM}]\left[\mathrm{PF}_{6}\right]$ mixtures showed absorbance maxima similar to the uranyl nitrate. The $[\mathrm{BMIM}]\left[\mathrm{PF}_{6}\right]$ compound is the least soluble of the three ILs in this study and therefore it was difficult to determine the presence of a U-IL complex using this method. In the presence of uranyl ion and [EtPy] $\left[\mathrm{CF}_{3} \mathrm{COO}\right]$ there was a shift in absorbance maximum to $408 \mathrm{~nm}$ from 402 and to $419 \mathrm{~nm}$ from 425 nm compared to uranyl nitrate alone. The observed shift to lower energy is most probably due to the electron withdrawing ability of the fluoride ions, confirming the complexation of uranyl ion with the IL.
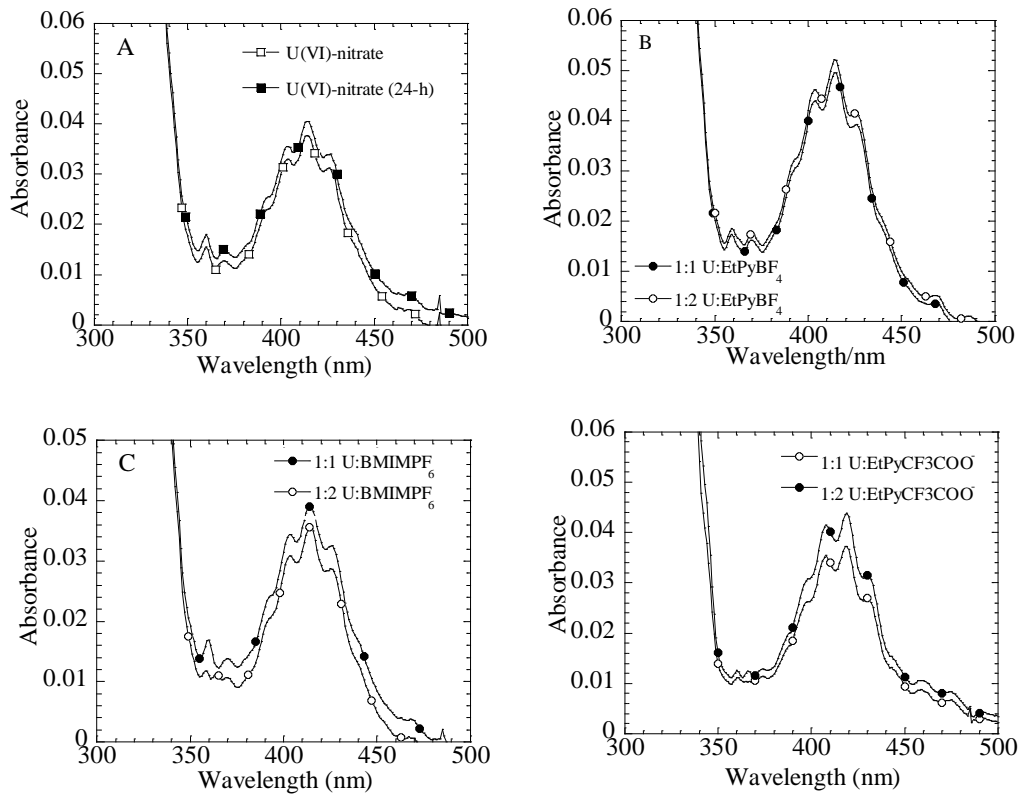

Fig 3. UV-vis spectrophotometry of uranium nitrate and U-IL mixtures: uranium-nitrate (A); [EtPy] $\left[\mathrm{BF}_{4}\right](\mathrm{B}) ;[\mathrm{BMIM}]\left[\mathrm{PF}_{6}\right](\mathrm{C}) ;[\mathrm{EtPy}]\left[\mathrm{CF}_{3} \mathrm{COO}\right](\mathrm{D})$.

Electrospray Ionization Mass Spectrometry (ESI-MS) analysis. In figure 4 uranium nitrate in water showed peaks at $270(\mathrm{~m} / \mathrm{z}), 287(\mathrm{~m} / \mathrm{z})$ and $305(\mathrm{~m} / \mathrm{z})$ due to the uranium ion and its association with hydroxyl ions in water. In the MS of 1:1 U: [EtPy] $\left[\mathrm{BF}_{4}\right]($ Fig 5), 108(m/z) is the molecular ion peak of N-ethyl pyridi- 
4 1Environmental Sciences Department, Brookhaven National Laboratory, Upton, NY, USA; 2Division of Advanced Nuclear Engineering, Pohang University of Science and Technology, Pohang, Korea

nium cation. The small peak at $418(\mathrm{~m} / \mathrm{z})$ may come from the anion exchange between uranium nitrate and $[\mathrm{EtPy}]\left[\mathrm{BF}_{4}\right]$.

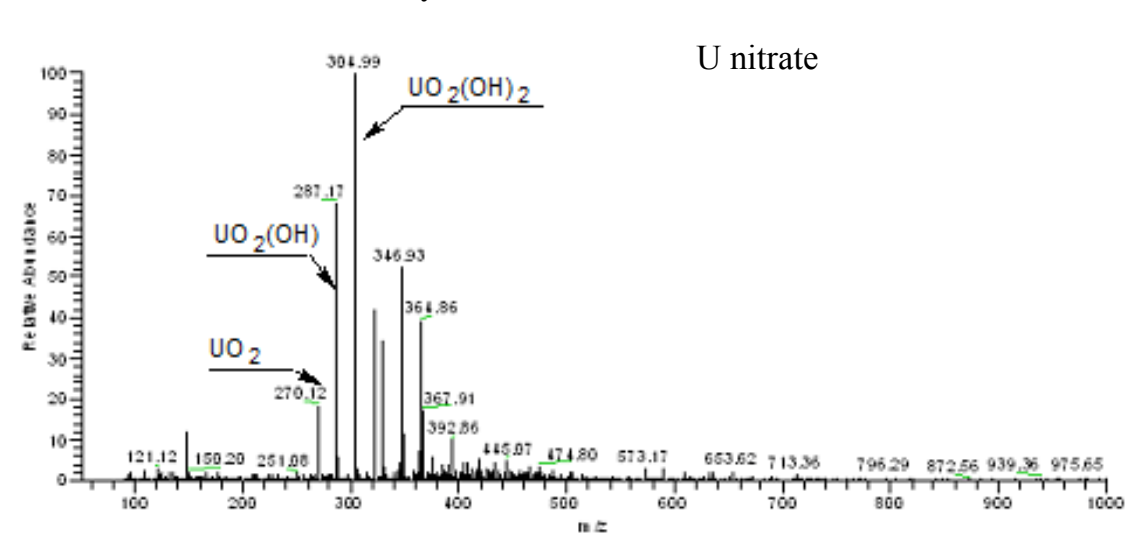

Figure 4. Mass spectroscopy of uranium nitrate in water under positive mode.

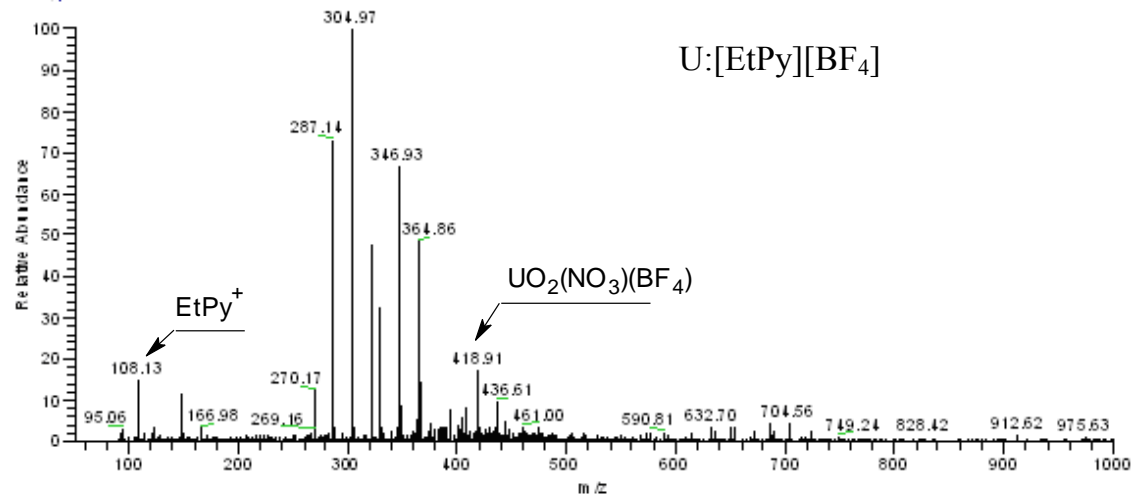

Fig 5. Mass spectroscopy of 1:1 U: $[\mathrm{EtPy}]\left[\mathrm{BF}_{4}\right]$ mixture under positive mode.

In Figure 6, the ESI-MS spectrum under negative mode for uranyl nitrate shows peaks at $365(\mathrm{~m} / \mathrm{z})\left[\mathrm{UO}_{2}\left(\mathrm{NO}_{3}\right)(\mathrm{OH})_{2}\right]^{-}$and $455(\mathrm{~m} / \mathrm{z})\left[\mathrm{UO}_{2}\left(\mathrm{NO}_{3}\right)_{3}\right]^{-}$. They are due to uranyl ion complexation with nitrate and hydroxyl ions. Figure 7 shows the ESI-MS spectrum under negative mode for U:[EtPy][CF3COO]. In addition to the peaks observed in Figure 6 for uranyl nitrate, there is a molecular ion peak at 413 $(\mathrm{m} / \mathrm{z})$. We believe the appearance of this peak is due to formation of $\left[\mathrm{UO}_{2}\left(\mathrm{NO}_{3}\right)(\mathrm{OH})\left(\mathrm{H}_{2} \mathrm{O}\right)(\mathrm{COO})\right]^{-}$species with loss of the $\mathrm{CF}_{3}$ moiety. 


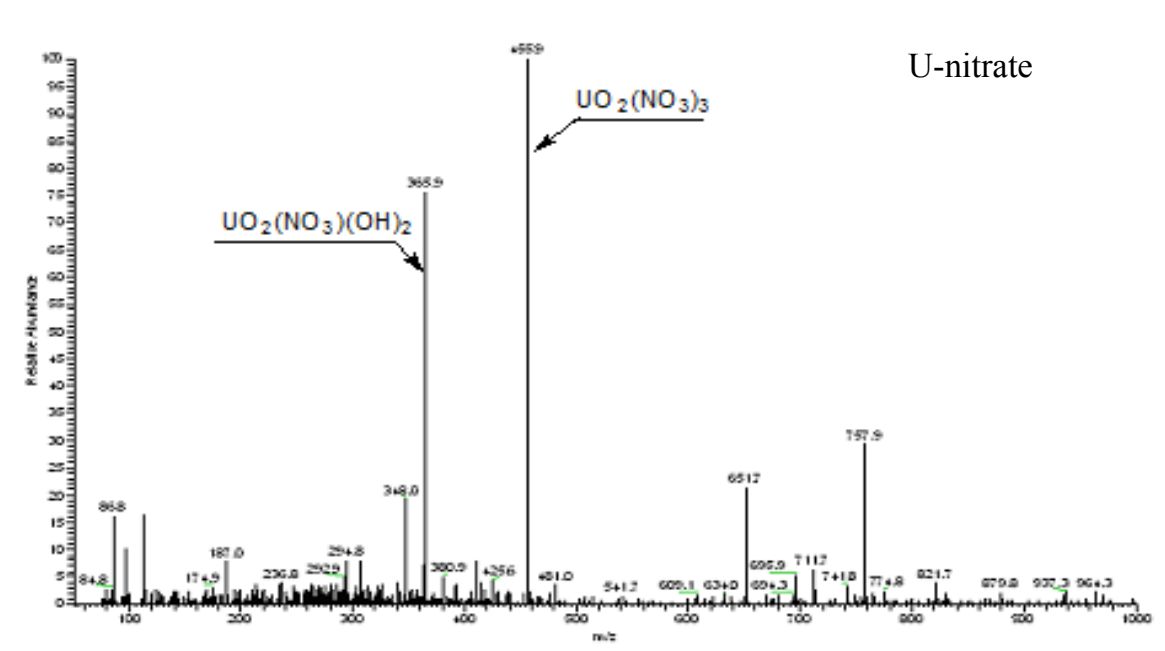

Fig 6 Electrospray ionization (ESI-MS) spectra under negative mode showing the molecular ions produced by uranyl nitrate solution.

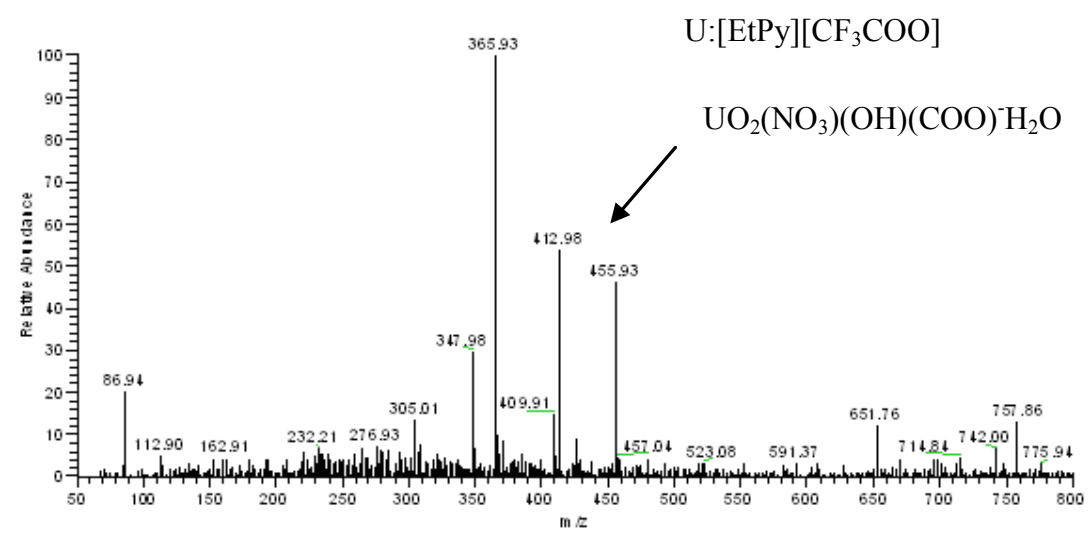

Fig 7. Electrospray ionization (ESI-MS) spectra undernegative mode showing the molecular ions produced by $\mathrm{U}:[\mathrm{EtPy}]\left[\mathrm{CF}_{3} \mathrm{COO}\right]$ solution.

X-ray Absorption Spectroscopy. X-ray Absorption Near-edge Spectroscopy (XANES) analysis of the absorption edge energies for U(VI)-nitrate and mixtures of U(VI)-nitrate and various ILs revealed that they have the same absorption edge energy $(17175 \mathrm{eV})$. This confirms that the U(VI) added to the IL's solution was present as U(VI) species and not reduced to U(IV). Extended X-ray absorption fine structure (EXAFS) spectroscopy analysis of the U ILs samples showed the following complexes formed between uranyl and [EtPy] $\left[\mathrm{BF}_{4}\right],[\mathrm{EtPy}]\left[\mathrm{CF}_{3} \mathrm{COO}\right]$, and $[\mathrm{BMIM}]\left[\mathrm{PF}_{6}\right]$ : monodentate complex between uranyl and $\mathrm{BF}_{4}^{-}$, and $\mathrm{PF}_{6}^{-}$, bi- 
6 1Environmental Sciences Department, Brookhaven National Laboratory, Upton, NY, USA; 2Division of Advanced Nuclear Engineering, Pohang University of Science and Technology, Pohang, Korea

dentate complex between uranyl and $\mathrm{CF}_{3} \mathrm{COO}$. Based on the ESI-MS and EXAFS results we propose the following structure (Fig 8).<smiles>O[W](O)(O)(O)(O)O</smiles>

a) $\mathbf{U O}_{2}{ }^{2+}$<smiles>O[PH](O)(F)O[W](O)(O)O</smiles>

c) $\mathrm{UO}_{2} \mathrm{BF}_{4}^{+}$

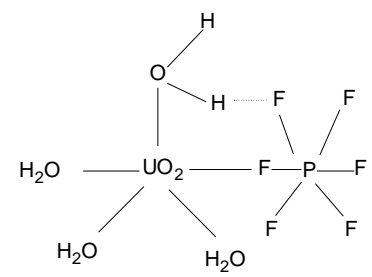

b) $\mathrm{UO}_{2} \mathbf{P F}_{6}^{+}$<smiles></smiles>

d) $\mathrm{UO}_{2}(\mathrm{OH})\left(\mathrm{CF}_{3} \mathrm{COO}\right)$

Fig 8. Proposed structures of U-Ionic Liquid complexes.

Effect of ILs on growth of Clostridium sp. Addition of ILs to bacterial growth medium affected the growth of Clostridium sp. as evidenced by decrease in optical density (Fig. 9).
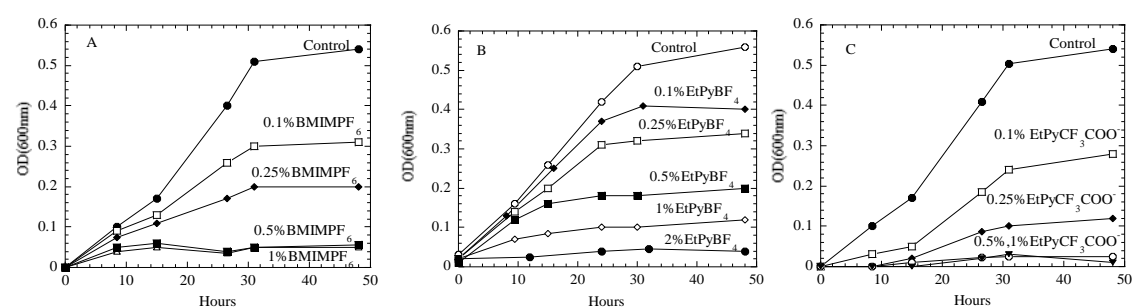

Fig. 9. Effects of IL on the optical density of Clostridium sp.

The optical density decreased with increase in concentration of [BMIM] $\left.\mathrm{PF}_{6}\right]$. Similar effects were observed with $[\mathrm{EtPy}]\left[\mathrm{BF}_{4}\right]$ and $[\mathrm{EtPy}]\left[\mathrm{CF}_{3} \mathrm{COO}\right]$ (Fig. 9B and $\mathrm{C}$ ). In comparison with $[\mathrm{EtPy}]\left[\mathrm{BF}_{4}\right]$, the two ILs, $[\mathrm{BMIM}]\left[\mathrm{PF}_{6}\right]$ and [Et$\mathrm{Py}]\left[\mathrm{CF}_{3} \mathrm{COO}\right]$, showed higher inhibition on the growth of Clostridium sp. Addition of $0.1 \%$ of $[\mathrm{BMIM}]\left[\mathrm{PF}_{6}\right]$ or $[\mathrm{EtPy}]\left[\mathrm{CF}_{3} \mathrm{COO}\right]$, the optical density decreased to 0.3 and 0.25 respectively. As the concentration of these two ionic liquids increased $>0.5 \%(\mathrm{~V} / \mathrm{V})$, no growth of bacteria was observed. 
After 48 hours incubation the $\mathrm{pH}$ of the medium changed from 5.5 to 3 due to organic acids produced from glucose metabolism. However, in presence of ILs, the growth was inhibited, and less glucose was consumed, thus less acids produced and the $\mathrm{pH}$ changed slowly. The drop in $\mathrm{pH}$ with the high concentrations of ILs may be due to the hydrolysis of ILs. Commensuration with growth, the amount of total gas, $\mathrm{CO}_{2}, \mathrm{H}_{2}$ production was less in ILs containing samples. We found that the growth of Clostridium sp and Pseudomonas fluorescens was affected by one more of these ILs (Wang et al. 2011; Zhang et al 2011; Nancharaih and Francis, 2011).

Effects of Ionic Liquids on Reduction of U(VI) by Clostridium sp. Addition of uranyl nitrate to growing culture of Clostridium sp. resulted in the rapid reduction of $\mathrm{U}(\mathrm{VI})$ to $\mathrm{U}(\mathrm{IV})$ which precipitated from solution (Fig 10A). In the presence of $[\mathrm{EtPy}]\left[\mathrm{BF}_{4}\right]$ reduction of $\mathrm{U}(\mathrm{VI})$ proceeded similar to uranyl nitrate but the concentration of reduced(IV) in solution was 3-fold higher and it precipitated much

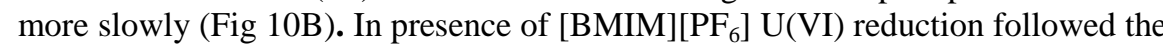
same pattern as uranyl nitrate (Fig.10C). Uranium which formed a bidentate complex with EtPy][ $\left.\mathrm{CF}_{3} \mathrm{COO}\right]$ was not reduced (Fig 10D).
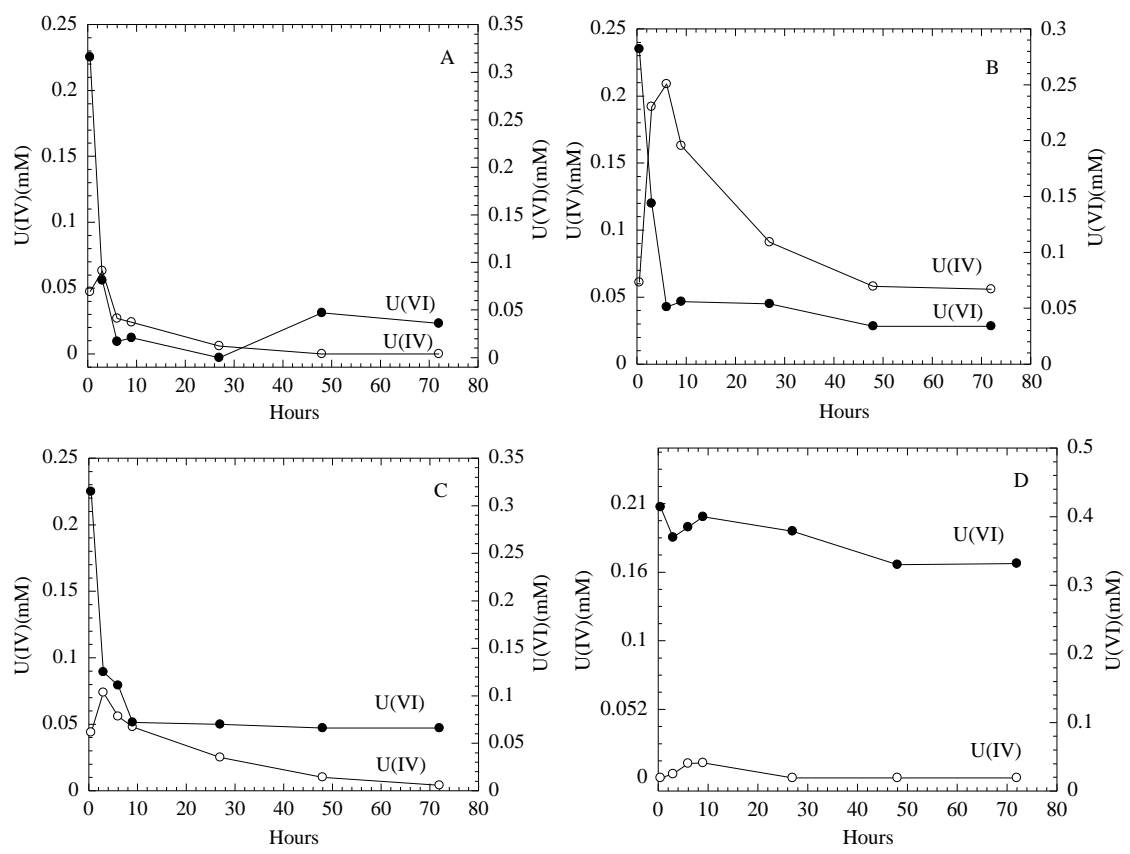

Fig. 10. Reduction of U(VI) by Clostridium sp in presence of various ILs: (A) uranyl nitrate; (B) $[\mathrm{EtPy}]\left[\mathrm{BF}_{4}\right]$; (C) $\left[\mathrm{BMIMPF}_{6}\right]$; (D) $[\mathrm{EtPy}]\left[\mathrm{CF}_{3} \mathrm{COO}\right]$.

Analysis of Uranium (VI) and U(IV) byUV-vis Spectroscopy. Uranium in the culture sample was extracted with citiric acid under anaerobic conditions and the absorption spectra of U(VI) and U(IV) were determined using a Hewlett Pack- 
8 1Environmental Sciences Department, Brookhaven National Laboratory, Upton, NY, USA; 2Division of Advanced Nuclear Engineering, Pohang University of Science and Technology, Pohang, Korea

ard 8453 diode array scanning UV-vis spectrophotometer. Before bacterial reduction, the maximum absorbance was at $435 \mathrm{~nm}$ which is the characteristic absorbance of U(VI). After bioreduction, the absorbance shifted to 555 and $665 \mathrm{~nm}$, which indicated the presence of U(IV) (Fig.11). XANES analysis showed energy shift from $17175 \mathrm{eV}$ to $17169 \mathrm{eV}$ indicating the reduction of U(VI) to U(IV).
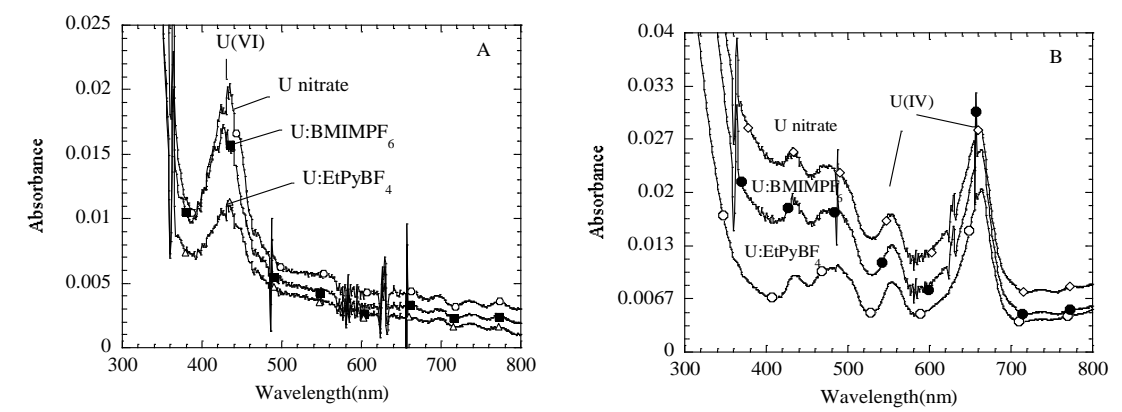

Fig. 11. UV-vis spectroscopy of precipitates extracted by citric acid (A) before bioreduction; (B) after bioreduction.

These results show that the ILs affected the growth of Clostridium sp. as evidenced by decrease in optical density, changes in the $\mathrm{pH}$ of the medium, total gas production and rate and extent of reductive precipitation of uranium.

Acknowledgement. We thank C.J. Dodge for assistance in XAS analysis and S.V. Malhotra for advice. This research was supported by Laboratory Directed Research and Development (LDRD) program at Brookhaven National Laboratory by the U.S. Department of Energy under contract No. DE-AC02-98CH10886 and in part by the World Class University (WCU) program through the National Research Foundation of Korea funded by the Ministry of Education, Science and Technology (R31 - 30005).

\section{References}

Anastas, P.T.; Warner, J.C. Green-Chemistry-Theory and Practice; Oxford University Press: New York, 1998.

Gaillard, C., Azzi, A. E., Billard, I., Bolvin, H., \& Hennig, C. 2005, Inorg. Chem. 44, 852 .

Visser, A.E.; Jensen, M.P.; Laszak, I.; Nash, K.L.; Choppin, G.R.; Rogers, R.D. 2003, Inorg. Chem., 42, 2197.

Wang, H., Malhotra, S.V., Francis, A.J. 2011, Chemosphere 82, 1597.

Zhang, C., Malhotra, S.V., Francis, A.J. 2011, Chemosphere 82, 1690.

Nancharaiah, Y.V. and Francis, A.J. 2011, Bioresource Technol. 102, 6573. 